\title{
Relationship between Numbers and Letters
}

\author{
Asmaa Rafat Elsaied
}

Received: March 30, 2016 / Accepted: April 25, 2016 / Published: August 25, 2016.

\begin{abstract}
This paper proposes that there is a relation between numbers and letters. This relation may exist in all types of different languages. This research focuses on the reason of choosing some mathematical symbols like "ط" and " $\pi$ " in Arabic, Latin, and English languages. Also, this paper presents some relations between months, weeks, and days in Arabic, English, and Latin languages.
\end{abstract}

Key words: Letters and numbers - " $\pi$ " letter - "b" letter.

\section{Introduction}

Throughout the ages people think that there is a tie between letters and numbers. In Hebrew, each letter corresponds to a number. As a result, any word or name can become a series of numbers. Numbers can be taken one at a time or added together. There is significance when words include or add up to the same numbers; the meanings of the words that share numbers are thought to be deeply related or even identical. [1]

Hebrew consists of 22 letters. The first nine letters, Aleph through Tet, represent the lower part of Bina. The next nine, Yod through Tzadik, stand for Zeir Anpin, and the last four, Kof through Tav, stand for Malchut, the creature itself.

In addition to the "regular" letters, there are five final letters in Hebrew. If you look at the illustration in Table 1, you will see that they are not new letters; they bear the same names as letters in the original 22.

Also, Muslims used abjad numerals, abjad numerals are decimal numerical system in which the 28 letters of the Arabic alphabet are assigned numerical values. In the abjad system the first letter of Arabic alphabet; alif (I) is used to represent 1 , the second letter ba (ب) is used to be represent by 2 etc...

They represent numbers from 1 to 9999 and this is clear evidence that every single detail have a significant meaning. The numbers in this system is represented by the alphabetic of Arabic letters and so that it was called Abjad numerals and the illustration is shown in Table 2:

There is a very lack of references that describe the relation between letters and numbers. This paper presents a new view to the relation between letters and numbers. It is tried to answer the question: Is the

Table 1 The Hebrew Letters and Their Numeric Values.

\begin{tabular}{|c|c|c|c|c|c|}
\hline $\mathrm{K}=$ Aleph & 1 & , = Yod & 10 & $P=K o f$ & 100 \\
\hline$\beth$ = Bet & 2 & $\supset=$ Chaf & 20 & $7=$ Reish & 200 \\
\hline$\lambda=$ Gimel & 3 & $\zeta=$ Lamed & 30 & $\mathscr{W}=$ Shin & 300 \\
\hline 7 = Dalet & 4 & sem = Mem & 40 & $\Omega=$ Tav & 400 \\
\hline $\boldsymbol{\pi}=\mathrm{Hey}$ & 5 & $J=$ Nun & 50 & & \\
\hline $1=$ Vav & 6 & ס = Samech & 60 & & \\
\hline$i=$ Zayin & 7 & $y=$ Ain & 70 & & \\
\hline$\pi=$ Het & 8 & $D$ = Peh & 80 & & \\
\hline$v=$ Tet & 9 & $\mathfrak{s}=$ Tzadik & 90 & & \\
\hline \multicolumn{6}{|c|}{ Final Letters: } \\
\hline & & \rceil$=$ Final Chaf & 20 & & \\
\hline & & $\Xi=$ Final Mem & 40 & & \\
\hline & & $j=$ Final Nun & 50 & & \\
\hline & & ๆ = Final Peh & 80 & & \\
\hline & & $\gamma=$ Final Tzadik & 90 & & \\
\hline
\end{tabular}

Table 2 The Arabic and English Letters and Their Numeric Values.

\begin{tabular}{|c|c|c|c|c|c|c|c|}
\hline A I & 1 & $\mathrm{H}$ ح & 8 & س S & 60 & $\mathrm{~T}$ & 400 \\
\hline تب B & 2 & I b & 9 & $O \varepsilon$ & 70 & U ث & 500 \\
\hline C & 3 & J & 10 & ف P & 80 & $\mathrm{~V} \dot{\tau}$ & 600 \\
\hline D د & 4 & K ك & 20 & ص Y & 90 & $Z$ ذ & 700 \\
\hline هـ & 5 & L J & 30 & Q Q Q & 100 & ضWW & 800 \\
\hline F g & 6 & $M$ ? & 40 & R J & 200 & I' ' & 900 \\
\hline G j & 7 & ن ن & 50 & ش ش & 300 & O' & 1000 \\
\hline
\end{tabular}


choice of symbols that represents constants done by chance or has certain reasonable idea. The author presents features of letter " $"$ " in representing the $\pi$-number and the similarity between " $b$ " and " $\pi$ " in Arabic and Latin languages. Also, the features of week days in Arabic and English languages say that there is a relation between letters and numbers.

\section{2. $\pi$-number}

The constant ratio is considered one of the most important mathematic numbers and constants. Years ago at the earliest of the human civilization, it gained its huge popularity specially with Egyptians, Greeks, Chinese and Indians. We can say that all different types of civilization cared about it. The amazing effect of $\pi$-number took place in architecture and calculations of areas and volumes.

The accretion and development of calculating the constant ratio represents the parallel development of the entire mathematic field.[2]

\subsection{Features of "מ"-Letter and $\pi$-number}

The Arabic letter $b$ is the sixteenth letter in the Arabic alphabets.

There are fifteen letters before the Arabic letter " $"$ " while there are twelve Arabic letters after it.

When the one multiply fifteen by twelve, the result equals one hundred and eighty $15^{*} 12=180$ which represents the number used to convert angle form to another

If we clearly observed the number of dots on the Arabic letters, we find that they are twenty two dots. Moreover, the number of the different-shaped Arabic letters are seven which represent the ratio 22/7.

The symbol " $\pi$ " is the first letter of the Greek word " $\pi \varepsilon \rho i ́ \mu \varepsilon \tau \rho о \varsigma$ ", which means the circumference. This symbol was used for the first time in 1706

The letter " $\pi$ ", in the Greek alphabets, is the sixteenth letter, and the number of the Arabic letter $b$ is the sixteenth as well as shown in Table 3.

Is it a chance?
Table 3 Arabic and English letters.

\begin{tabular}{|c|c|c|c|c|}
\hline أ & ب... & 3....ت & $4 \ldots$ & 5... \\
\hline $6 \ldots .2$ & $7 \ldots . \dot{C}$ & $8 \ldots{ }^{2}$ & 9....ذ & $10 \ldots . .$. \\
\hline $11 \ldots . . j$ & س..... & ش..... & ص....14 & ض....15 \\
\hline 16.... & ظظ..... & $18 \ldots \varepsilon$ & $19 \ldots \dot{\varepsilon}$ & ف.... \\
\hline ق....21 & ك.... & J.... & 24.... & ن \\
\hline $26 \ldots . .$. & $27 \ldots 9$ & ي.....28 & & \\
\hline
\end{tabular}

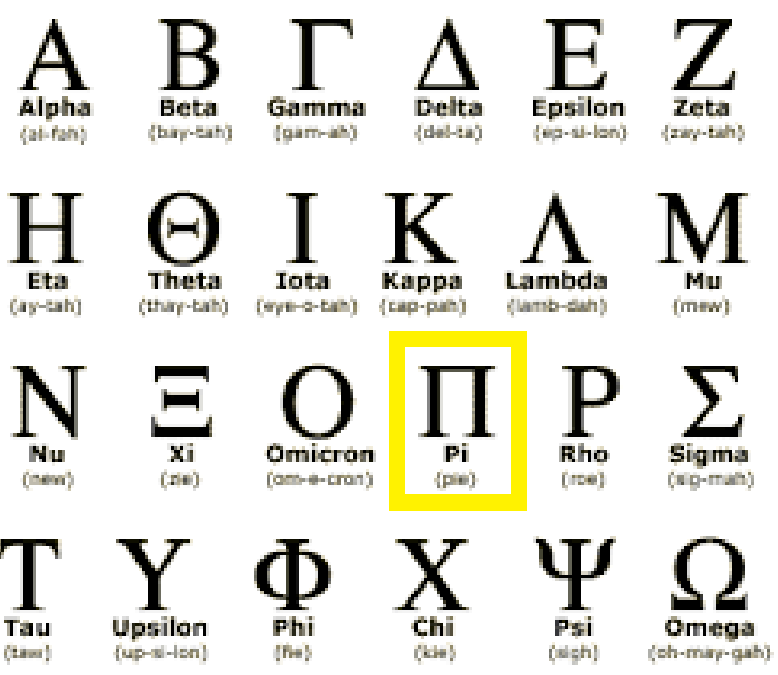

\section{Features of Week days (ايام الاسبوع) in Arabic} and English languages

A week is a time unit equal to seven days. It is the standard time period used for cycles of work days and rest days in most parts of the world, mostly alongside (but not strictly part of) the Gregorian calendar.

The days of the week were named in different languages after classical planets, various deities (example: Thursday - Thor's day, a variation after Jupiter's day from Roman times) and heavenly bodies (example: Sunday - Sun's day) and other sources. In English, the names are Monday, Tuesday, Wednesday, Thursday, Friday, Saturday and Sunday.

The term "week" is sometimes expanded to refer to other time units comprising a few days, such as the nominal cycle of the ancient Roman calendar.

\section{Methodology}

The Arabic letters are ordered as given in Table 3 and each letter has a number from 1 to 28. In English language the letters are ordered $\mathrm{a} b \mathrm{c}, \ldots, \mathrm{y}, \mathrm{z}$ and each letter has a number from 1 to 26 . The letters that its 
capital shape is different from its small shape are chosen as shown in Table 4.

Compute the number representing the day which is the sum of the numbers representing the day as shown in Table 5.

Table 4 Non-shaped letters in English Language.

\begin{tabular}{|l|l|l|}
\hline A & a & 1 \\
\hline B & b & 2 \\
\hline D & d & 4 \\
\hline E & e & 5 \\
\hline G & g & 7 \\
\hline H & h & 8 \\
\hline I & I & 9 \\
\hline$J$ & j & 10 \\
\hline M & m & 13 \\
\hline N & n & 14 \\
\hline Q & q & 17 \\
\hline R & r & 18 \\
\hline T & t & 20 \\
\hline
\end{tabular}

Table 5

\begin{tabular}{|c|c|}
\hline اللغه الانجليزيه & اللغه العربيه \\
\hline $\begin{array}{l}\text { SATUR DAY: } \\
1+20+18+4+1=44\end{array}$ & سبت: 12+2+3=3 \\
\hline $\begin{array}{l}\text { SUN DAY: } \\
14+4+1=19\end{array}$ & احد : 1+6+8=8=15 \\
\hline $\begin{array}{l}\text { MON DAY: } \\
13+14+1+4=32\end{array}$ & اثثين: 1+4+25+28+25=25 \\
\hline $\begin{array}{l}\text { TUES DAY: } \\
20+5+1+4=30\end{array}$ & ثلاث : 4+23+1+1+4 =32 \\
\hline $\begin{array}{l}\text { WEDNES DAY: } \\
5+4+14+5+4+1=33\end{array}$ & اربع : 1+10+2+18=31 \\
\hline $\begin{array}{l}\text { THURS DAY: } \\
20+8+18+4+1=51 \\
\end{array}$ & خميس : 5 +24+28+12 =12 \\
\hline $\begin{array}{l}\text { FRI DAY: } \\
18+9+4+1=32\end{array}$ & جمعه : 5+24+18+26 =26 \\
\hline Sum $=241$ & المجموع = 322 \\
\hline
\end{tabular}

Add the in

The same rule must be applied to Arabic and english Saturday the word equal 44 when we add $4+4=8$.

Sunday the word equal 19 when we add $1+9=10$.

Monday $=32$ when add $3+2=5$,

TUES DAY $=30 \ldots .3+0=3$,

WEDNES DAY $=33 \ldots 3+3=6$.

THURSDAY $=51 \ldots 5+1=6$.

FRI DAY $=32 \ldots 3+2=5$,

When we add $8+10+5+3+6+6+5=43$
The number $34 \ldots .$. when add between number $4+3=$ week

The number $34 \ldots .$. when subtraction between number 4-3 =day

The number $34 \ldots$ when multiply between number $4 * 3=$ year

Table 6

\begin{tabular}{|l|l|l|l|l|}
\hline SATUR DAY & 44 & $4+4$ & 8 & 8 \\
\hline SUN DAY & 19 & $1+9$ & 10 & 1 \\
\hline MON DAY & 32 & $3+2$ & 5 & 5 \\
\hline TUES DAY & 30 & $3+0$ & 3 & 3 \\
\hline WEDNES DAY & 33 & $3+3$ & 6 & 6 \\
\hline THURS DAY & 51 & $5+1$ & 6 & 6 \\
\hline FRI DAY & 32 & $3+2$ & 5 & 5 \\
\hline Sum & 241 & & 43 & 34 \\
\hline
\end{tabular}

\begin{tabular}{|c|c|c|c|c|}
\hline سبت & 17 & $1+7$ & 8 & 8 \\
\hline احد & 15 & $1+5$ & 6 & 6 \\
\hline اثنين & 83 & $8+3$ & 11 & $1+1$ \\
\hline ثلاث & 32 & $3+2$ & 5 & 5 \\
\hline اربع & 31 & $3+1$ & 4 & 4 \\
\hline خمبس & 71 & $7+1$ & 8 & 8 \\
\hline جمعه & 73 & $7+3$ & 10 & $1+0$ \\
\hline المجموع & 322 & & 52 & 34 \\
\hline
\end{tabular}

1: and so when we add the results of the Arabic days we will notes that their total is 322 and when we add between the number we will notes that $3+2+2=7$ and this is the day of the week

2: we will chose the capital letters which different from its shape in small to count the word when we add the English days the result leads to 241 and when we add between the number $2+4+1=7$ and this is the day of the week

\section{References}

[1] http://www.kabbalah.info/eng/content/view/frame/60270 ?/eng/content/view/full/60270\&main

[2] Mathematics+and+Its+History+-+\%5bMei+\%5djohn+Sti 1lwell_937

[3] https://www.google.com.eg/url?sa $=t \& r c t=j \& q=\&$ esrc $=s \&$ source $=$ web $\&$ cd $=1 \&$ cad $=$ rja $\&$ uact $=8 \&$ ved $=0$ ahUKEwjij 6 Hx6OrLAhUrA3MKHUbyBK0QFggfMAA\&url=https\% 3A\%2F\%2Fen.wikipedia.org\%2Fwiki\%2FWeek\&usg=A FQjCNGT1mcVjQvYhmJm5dz0Qf2QgtIQXQ\&bvm=bv. 118443451, d.bGQ 